\title{
Je li ljudska seksualnost humana i osobna?
}

\author{
Tadija Milikić*
}

\begin{abstract}
Sažetak
Članak nastoji pridonijeti razumijevanju ljudske seksualnosti osobito iz perspektive belgijskog moralnog teologa Servaisa Pinckaersa, koji nastoji slijediti autentičnu Akvinčevu misao, i koji se nalazi na liniji najnovijih dokumenata crkvenog učiteljstva. Prvi i drugi dio članka pridonose ispravnijemu tumačenju "animalne" $i$ »naravne" dimenzije ljudske seksualnosti, ističući da ljudska seksualnost ima i animalnu i naravnu dimenziju, ali da se ne smije svesti ni na animalnu seksualnost ni na narav koja ne bi bila jedna i jedinstvena ljudska narav. Treći i najvažniji dio članka nastoji ukazati na humanu i osobnu dimenziju seksualnosti, kao na ono bez čega je ljudska seksualnost nezamisliva, odnosno kao na ono što ljudskoj seksualnosti daje njezinu posebnu, vlastitu i neotudivu antropološku vrijednost. I konačno, sveukupna refleksija članka neizravno upućuje na nadnaravnu dimenziju ljudske seksualnosti.

Ključne riječi: seksualnost, animalnost, naravnost, supstancijalno jedinstvo, humanost, dobro, osoba, Servais Pinckaers, sv. Toma Akvinski
\end{abstract}

\section{Uvod}

Polazište je članka nauk o seksualnoj sklonosti, koji se nalazi u zadnjem sedamnaestom poglavlju najvažnijeg djela belgijskog teologa Serveisa Pinckaersa (1925. - 2008.) Izvori kršćanske etike, koje je prevedeno gotovo na sve velike europske jezike. Poglavlje je naslovljeno: Naravne sklonosti na izvoru slobode $i$ moralnosti, a zapravo uglavnom slijedi nauk o naravnom zakonu kod sv. Tome Akvinskog (1225. - 1274.). Članak se nadahnjuje također na veoma bogatim, dubokim i plodnim kategorijama Akvinčeve misli, koja je prisutna ne samo u Akvinčevim djelima, nego također u dokumentima suvremenog crkvenog učiteljstva. Središnja je ideja cijelog članka ukazati na nužni kontekst, neotuđivu perspektivu i neupitni temelj ispravnog razumijevanja i tumačenja ljudske seksualnosti. Članak nema za cilj dati iscrpno i sveobuhvatno izlaganje o ljudskoj seksualnosti, a još manje sustavno ulaziti u određena antropološka i dogmatska

* Dr. sc. Tadija Milikić, docent, Sveučilište u Zagrebu — Fakultet za filozofiju i religijske znanosti u Zagrebu. Adresa: Jordanovac 110, 10000 Zagreb, Hrvatska. E-pošta: tmilikic@ffdi.hr 
pitanja koja se tiču ljudske slobode i ljudskoga grijeha, koji se nalaze u korijenu pale ljudske naravi, kao i u korijenu ljudske požude i slabosti, koji su itekako prisutni na području seksualnosti. Štoviše, članak nema za cilj ni dublje propitkivanje ljudske naravi, nego želi tek ukazati na odlučujuću i temeljnu važnost iste naravi i dosljedno ljudske osobe za ispravno razumijevanje i tumačenje ljudske seksualnosti. Nadalje, članak se izravno ne bavi ni odnosom naravi i nadnaravi na području ljudske seksualnosti, ali neizravno cijelom svojom refleksijom, osim što upućuje na nadnaravnu dimenziju, također ukazuje na njezinu neupitnu i temeljnu važnost za ispravno razumijevanje ljudske seksualnosti. Suvremena kultura i određene misaone kategorije u njoj prisutne neposredno su idejno polazište članka, ukoliko ukazuju na redukcionistički, neprimjeren i racionalno neprihvatljiv pristup u razumijevanju i tumačenju stvarnosti ljudske seksualnosti. Uz animalistički i naturalistički redukcionizam, članak nastoji ukazati također na neprimjerenost antropološkog dualizma na području ljudske seksualnosti.

\section{Je li ljudska seksualnost animalna?}

Kao istaknuti predstavnik tomističke struje 20. stoljeća, belgijski moralni teolog Servais Pinckaers i u tom pitanju oslanja se osobito na nauk sv. Tome Akvinskog. Zajedno s njim, svoj govor o naravnoj seksualnoj sklonosti Pinckaers smješta u nauk o naravnim sklonostima, odnosno u nauk o naravnom zakonu, koji je normativni izraz naravnih sklonosti. ${ }^{1} \mathrm{U}$ Akvinčevu klasičnom poretku od pet temeljnih naravnih sklonosti, kako ih donosi Pinckaers, seksualna sklonost zauzima treće mjesto, i prema prijevodu istaknutog hrvatskog tomista druge polovice 20. stoljeća, dominikanca Tome Vereša (1930. — 2002.), Akvinac ovako piše o naravnoj seksualnoj sklonosti: »[...] u čovjeka je usađena sklonost prema nekim posebnim dobrima, sukladnim s njegovom naravi, koja su mu zajednička s ostalim osjetilnim bićima. A u tom pogledu kaže se da u naravni zakon spada 'ono što je narav naučila sva osjetilna bića' (op. autora), na primjer sjedinjenje muškarca i žene, odgoj djece i slično. « Tko pročita izvornik tog navoda u bilješci ispod teksta, odmah će uočiti određenu poteškoću između Akvinčeva izraza animalia i Vereševa prijevoda osjetilna bića. U korijenu te poteškoće vjerojatno se, barem dijelom, nalazi i ono na što želi ukazati ovo poglavlje.

1 Dobro je imati na umu da postoji unutarnji, a ne samo onaj izvanjski odnos između naravnih sklonosti i naravnog zakona, odnosno između naravne seksualne sklonosti i naravnog, tj. temeljnog ljudskog zakona: »Čini dobro, izbjegavaj zlo!«Usp. Servais Pinckaers, The Sources of Christian Ethics, Edinburgh, 2001, 404-405. Usp. Papinska međunarodna teološka komisija, In Search of a Universal Ethic: A New Look at the Natural Law, 2009, 42. i 45.

2 Toma Akvinski, Izabrano djelo, Tomo Vereš (prev.), Zagreb, 2015, 491. Poradi usporedbe s latinskim izvornikom S. Thomae Aquinatis, Summa Theologica, Taurini, 1820, vol. 2, I-II,94,2, uz izvornik, donosi se također prijevod istog izvornika na engleski i talijanski jezik. Za razliku od hrvatskog, engleski i talijanski prijevod zadržavaju riječ »životinja«, koja je prisutna u izvorniku: »quae natura omnia animalia docuit «, »which nature has taught to all animals«, »le cose che la natura ha insegnato a tutti gli animali 
Kada govori o seksualnoj sklonosti, koja čovjeka usmjerava na seksualno sjedinjenje, na prokreaciju i na odgoj vlastitog potomstva, Akvinac povezuje ljudsku seksualnost sa željom koja mu je zajednička s animalnim, tj. životinjskim svijetom. Takav pristup ukazuje na kontinuitet s prijašnjom latinskom tradicijom, u kojoj se napose ističe Ciceron (106. - 43. pr. Kr.), koji tvrdi da je »svim životinjama zajedničko da se žele sjediniti zbog prokreacije i da se brinu za one koji su se rodili ${ }^{3}{ }^{3}$ Međutim, ta poveznica između ljudske i animalne seksualnosti otvara mogućnost da je se krivo shvati i protumači, s jedne strane zbog negativne konotacije izraza »životinja«, a s druge strane zbog poprilično ograničenog i površnog pogleda na bogatu i duboku stvarnost ljudske seksualnosti. Prva poteškoća može se lako razriješiti ako se ima na umu da poveznica između ljudske i životinjske seksualnosti nema nikakvu negativnu, obezvređujuću ili ponižavajuću konotaciju. Naime, za razliku od suvremenih misaonih kategorija koje daju prizvuk negativnosti izrazu »životinja«, isti izraz moralno je neutralan i kod sv. Tome Akvinskog, kao i kod sveukupne tradicije koju on baštini. U toj tradiciji spomenuti izraz uopće nema negativnu, nego dapače pozitivnu konotaciju. On naime ukazuje na biće koje ima život, ili još bolje, na biće koje je obdareno životom i dosljedno osjetilnom spoznajom. Na toj animalnoj i osjetilnoj razini seksualnost je moralno neutralna i zajednička je čovjeku i životinji. Kod nje se ne gleda koliko je razumna, tj. podložna razumu i volji, nego koliko je osjetilna, tj. podložna osjetilnoj spoznaji i osjetilnoj težnji. ${ }^{4}$

S obzirom na drugu poteškoću, ne treba posebno isticati da ljudska seksualna sklonost nužno uključuje tjelesnu, odnosno osjetilnu dimenziju. Ustvari, upravo je to ta dimenzija koja je zajednička ljudima i životinjama. I jedni i drugi obdareni su životom, osjetilnom spoznajom i osjetilnom težnjom. Međutim, uz tu tjelesnu, odnosno osjetilnu dimenziju, koja je zajednička ljudima i životinjama, čovjek ima i svoju vlastitu razumsku, humanu i osobnu dimenziju, svoje tipične ljudske sklonosti, one koje se prije svega tiču njegove razumske, duhovne i osobne razine postojanja: a to su, kao što je poznato, prije svega sklonost prema dobru i sklonost prema istini. Osim što pripadaju čovjeku kao njegove vlastite i osim što bitno obilježavaju njegovo postojanje i djelovanje, te tipične ljudske sklonosti upravljaju svim ostalim naravnim, tj. ljudskim sklonostima, uključujući i onu seksualnu. ${ }^{5}$ Treba sasvim jasno istaknuti da sv. Toma, ukazujući na ono što je zajedničko između ljudske i životinjske seksualnosti, ne želi prvu niti spustiti na razinu druge, niti je njome ograničiti, nego samo ukazati na ono što je čovjeku zajedničko sa svim životinjama na području naravne, tj. ljudske seksualne sklonosti.

Imajući na umu dosada rečeno, Pinckaers s pravom ističe da se seksualnost u čovjeku ostvaruje na drugačiji i daleko bogatiji način nego u životinjama, jer je

3 Cicero, De officiis, New York, 1928, I, IV. URL: https://archive.org/stream/deofficiiswithen00 ciceuoft\#page/n9/mode/2up (preuzeto 05.12.2016.) [Prijevod Tadija Milikić.]

4 Usp. Servais Pinckaers, nav. dj., 437; S. Thomae Aquinatis, nav. dj., vol. 2, I-II,24,1.

5 Usp. Servais Pinckaers, nav. dj., 422; S. Thomae Aquinatis, nav. dj., vol. 2, I-II,94,2; Cicero, nav. dj., I, IV. 
ljudska seksualnost sastavni i konstitutivni dio jedne jedine, jedinstvene i cjelovite ljudske naravi, u kojoj prije svega dominiraju izrazito antropološke sklonosti prema dobru i prema istini, sklonosti koje u čovjeku zajedno s ostalim naravnim sklonostima stvaraju jednu jedinstvenu unutarnju, razumsku i duhovnu spontanost. ${ }^{6} \mathrm{Na}$ tom tragu nalazi se i već spomenuti Ciceron, koji je snažno utjecao na sveukupnu latinsku tradiciju. Nakon što je ustvrdio da je ljudska želja za prokreacijom i brigom za potomstvo nešto što je čovjeku zajedničko sa svim životinjama, odmah zatim Ciceron ukazuje na temeljnu razliku koja postoji između čovjeka i životinje, a to je da se životinja oslanja na svoja osjetila, a čovjek uz njih još se više oslanja na razum, koji traži sklad u svemu, osobito na razini misli, riječi i djela. Uz ono osjetilno dobro, tj. ono što je u skladu s njegovom osjetilnošću, prema Ciceronu, čovjek još više traži ono dobro koje je u skladu s njegovom razumnošću. To dobro je ljudsko dobro u najistaknutijem smislu riječi, i ono najviše koristi čovjeku. U njemu Ciceron prepoznaje čestito, odnosno moralno dobro (honestum), dobro koje se želi u njemu samom i poradi njega samog, dobro koje najviše odgovara ljudskoj razumnoj naravi. ${ }^{7}$

U kratkom zaključku ovog poglavlja, na tragu antičke i skolastičke tradicije koju predstavljaju Ciceron i sv. Toma Akvinski, moglo bi se istaknuti da je, poput animalne, i ljudska seksualnost obdarena životom i osjetilnošću. Međutim, za razliku od prve, druga, tj. ljudska seksualnost obdarena je također razumom, koji bitno određuje ne samo razumsku, nego također i onu osjetilnu spoznaju i težnju.

\section{Naravnost ljudske seksualnosti}

$\mathrm{Za}$ ispravno razumijevanje naravne seksualne sklonosti, tj. seksualne sklonosti koja je čovjeku naravna, dobro je pozabaviti se barem nakratko ispravnim tumačenjem prve riječi u izrazu »naravna seksualna sklonost «. Osobito stoga što neispravno razumijevanje te riječi nerijetko navodi kako na krivo razumijevanje ljudske seksualnosti danas, tako i na pogrešno iščitavanje i tumačenje određenih osobito starijih dokumenata o ljudskoj seksualnosti. Naime, ne smijemo zaboraviti da je suvremeni čovjek pod utjecajem ne samo različitih antropologija, od kojih svaka na svoj način tumači ljudsku narav, nego i pod snažnom dominacijom pozitivnih znanosti i njezinih misaonih kategorija, koje na jedan redukcionistički ili bolje reći pozitivistički način tumače narav.

Prije svega valja istaknuti da se »narav« može razumjeti na više načina, jer je riječ o analognom pojmu. Primjerice, kada se ustvrdi da je nešto naravno, tada se može misliti isključivo na ono čime se bave prirodoslovne znanosti, kao što su fizička, biološka i kemijska stvarnost. Ali može se misliti i na ono čime se ne

6 Usp. S. Thomae Aquinatis, nav. dj., vol. 2, I-II,94,2; Papinska međunarodna teološka komisija, nav. dj., 39-46, osobito 39. i 41; Servais Pinckaers, nav. dj., 452.

7 Usp. Cicero, nav. dj., I, IV; Marcus Tullius Cicero, O krajnostima dobra i zla, Petar Pejčinović (s lat. preveo i napisao komentar), Sarajevo, 1975, I, IV; Cicero, De finibus bonorum et malorum, New York, 1914. URL: https://ryanfb.github.io/loebolus-data/L040.pdf (preuzeto 05.12.2016.) 
bave prirodoslovne znanosti. Naime, pod onim što je naravno može se misliti na ono što po samoj naravi pripada bićima čisto duhovne stvarnosti, kao što sveprisutnost sasvim naravno pripada anđelima, koji nisu ograničeni ni vremenom, ni prostorom. Problem se još više uočava ako se izgubi iz vida da ljudska narav nije ni životinjska ni anđeoska narav, nego jedna drugačija narav, koja ima nešto zajedničko sa životinjama, a isto tako ima nešto zajedničko s anđelima. Za razliku od životinjske naravi, ljudska narav uključuje duh, a za razliku od anđeoske naravi uključuje tijelo. Ljudska je narav jedna jedina narav, narav koja nije sastavljena od dvije naravi, nego narav u kojoj se nalaze dvije dimenzije. To znači da su obje dimenzije uzajamno povezane na supstancijalan, a ne akcidentalan način, odnosno to znači da obje dimenzije postoje na način jedne jedinstvene naravi, naravi koja ima svoje posebno ime, i koja se zove ljudska narav. Naime, čovjek po samoj svojoj ljudskoj naravi ima i tijelo i duh. On je i tjelesan i duhovan. I stoga sve ono što je u skladu s njegovom naravi, kako na razini tijela, tako i na razini duha, može se reći da je čovjeku naravno, i to u onoj mjeri u kojoj je u skladu s njegovom ljudskom naravi.

Treba naglasiti da se u članku ne govori o bilo kojoj naravnoj seksualnoj sklonosti, nego o ljudskoj seksualnoj sklonosti, sklonosti koja je sastavni i konstitutivni dio ljudske naravi, i koja se upravo zato zove ljudska seksualna sklonost, a ne životinjska seksualna sklonost. Naime, i ljudi i životinje imaju seksualnost po samoj svojoj naravi, tako da je seksualnost i jednih i drugih naravna seksualnost. Međutim, kod prvih je riječ o ljudskoj seksualnosti, a kod drugih je riječ o životinjskoj seksualnosti. Jedna je humana, a druga životinjska seksualnost. Za razliku od životinje koja ima animalnu narav i dosljedno animalnu seksualnost, čovjek ima humanu narav i dosljedno humanu seksualnost. Stoga, čovjek ima seksualnost utoliko ukoliko ima ljudsku, a ne ukoliko ima životinjsku narav, odnosno čovjek ima seksualnost utoliko ukoliko je čovjek, a ne ukoliko je životinja.

\section{Ljudska seksualnost}

Za razliku od prethodna dva poglavlja koja govore o ljudskoj seksualnosti iz perspektive animalnosti i naravi u njezinu najopćenitijem smislu, ovo poglavlje nastoji ukazati na ljudsku seksualnost ukoliko je ljudska seksualnost, seksualnost ne bilo koje, nego jedne jedine, cjelovite, posebne i jedinstvene ljudske naravi, osobito u njezinu najistaknutijem smislu. Taj pristup je integralniji, pozitivniji, afirmativniji i čovjeku primjereniji. Ne dovodi u pitanje i ne niječe onu dimenziju ljudske seksualnosti koja je ljudima i životinjama zajednička, nego ukazuje prije svega na onu dimenziju iste seksualnosti koja je vlastita čovjeku kao čovjeku.

\subsection{Antropološka dimenzija seksualnosti}

U skladu s klasičnom definicijom ljudske naravi animal rationale, kao i temeljnim postavkama Akvinčeve nauke o ljudskoj naravi, čovjek ima nužno i tjelesnu 
i duhovnu dimenziju, i kao takav on nije zamisliv ni bez jedne ni bez druge dimenzije svojeg postojanja. Kao što ne postoji čovjek bez tijela, tako ne postoji ni čovjek bez duha. A budući da su ljudsko tijelo i ljudski duh povezani na razini supstancijalnog jedinstva, sasvim je logično zaključiti da je nemoguće razumjeti jedno bez supstancijalnog odnosa s drugim. ${ }^{8}$ Osim toga, ako se ima na umu Aristotelov nauk o aktu i potenciji, odnosno njegov nauk o materiji i formi, onda treba istaknuti da je ljudski duh u čovjeku aktivno i formalno načelo, a ljudsko tijelo materijalno i pasivno načelo. Dobro je istaknuti da Aristotelov nauk priznaje i afirmira oba načela, ali ipak daje prednost jednomu od njih, tj. aktu odnosno formi. ${ }^{9}$

$\mathrm{Na}$ tom tragu nalaze se i suvremena misaona moralna kretanja koja propitkuju podrijetlo moralne normativnosti ljudske naravi i koja vode računa o tome da je uvijek riječ o jedinstvenom, cjelovitom i konkretnom čovjeku. Čuvajući se i naturalizma, koji zanemaruje ljudski duh, kao i spiritualizma, koji zanemaruje ljudsko tijelo, sasvim je očito da je nužno vrednovati i jedno i drugo kao ono što supstancijalno određuje čovjeka, ali ipak ne vrednovati ih na isti način, nego u skladu s njihovom stvarnom ulogom i vrijednošću koje imaju u ljudskom životu. Stoga, u ljudskom tijelu prepoznaje se supstancijalan, bitan, relevantan i nužan element za ispravno razumijevanje ljudske normativne naravi, ali prednost se ipak daje ljudskomu duhu, koji uz ono supstancijalno, bitno, relevantno i nužno ukazuje također na ono što je izvrsnije i odlučnije u čovjeku kao čovjeku: a to je ljudski um i razum te ljudska volja i sloboda. ${ }^{10}$

Na temelju svega do sada rečenog može se ustvrditi da je ljudsku seksualnost nemoguće razumjeti bez vrednovanja ne samo ljudskoga tijela, nego i ljudskog duha. Isto tako, moguće je zaključiti da u uzajamnom odnosu ljudskog duha i tijela prednost treba dati ljudskomu duhu, koji ima ne samo aktivnu i formalnu, nego također odličniju i odlučniju ulogu u ljudskom životu i dosljedno ljudskoj seksualnosti. Treba ustvrditi da se u samim temeljima propitkivanja o ljudskoj seksualnosti nalazi antropološko propitkivanje o temeljnoj strukturi ljudske naravi. Premda se pitanjem tko je i što je čovjek osobito bavi filozofska i teološka antropologija, ipak isto pitanje nužno zanima i svakoga tko se bavi izlaganjem i tumačenjem ljudske seksualnosti. Ako razumijevanje ljudske stvarnosti, odnosno čovjeka, bitno uvjetuje tumačenje ljudske seksualnosti, onda nije svejedno koja je antropologija u pozadini određenog razumijevanja ljudske seksualnosti. A to znači da je nemoguće imati ispravno izlaganje o ljudskoj seksualnosti ako mu ne prethodi isto tako ispravno shvaćanje ljudske naravi. I konačno, nemoguće je govoriti o ljudskoj seksualnosti ako joj se zaniječe njezino antropološko uteme-

8 Usp. S. Thomae Aquinatis, nav. dj., vol. 1, I,75-76.

9 Usp. Aristotel, Metafizika, Tomislav Ladan (prev.), Zagreb, 1985, osobito VI-IX; Borislav Dadić, Aristotelov nauk o aktu, Filozofska istraživanja, 27/4 (2007), 765-776.

10 Usp. Klaus Demmer, Shaping the Moral Life: An Approach to Moral Theology, Roberto dell'Oro (prev.), Washington, 2000, osobito 40-42; usp. Drugi vatikanski koncil, Deklaracija o slobodi vjerovanja, »Dignitatis humanae«, 2-3. U: Drugi vatikanski koncil, Dokumenti, Zagreb, 2008, 485-489; Papinska međunarodna teološka komisija, nav. dj., 70. 
ljenje i značenje, odnosno ako se ljudskoj seksualnosti ne prizna njezina duboka i unutarnja povezanost s ljudskim duhom, ljudskim razumom i dosljedno s ljudskom slobodom.

\subsection{Humanost ljudske seksualnosti}

Uz filozofsku i teološku antropologiju, u ljudsku narav i ono što se misli pod humanosti uvode nas na poprilično sugestivan način i neke vrlo jednostavne rečenice iz svakidašnjeg iskustva, kao što su tvrdnje: »On je uistinu ljudina! «; »To je human čovjek! «; »To je pravi čovjek!« Ne ulazeći u nešto opširniju i dublju filozofsku ili teološku antropološku analizu spomenutih izraza, može se ustvrditi već na razini zdravog razuma da se ono što se krije pod izrazom »humanost« s lakoćom pripisuje čovjeku koji se u svojem djelovanju usmjeruje na istinsko i potpuno dobro, tko traži dobro u svoj njegovoj univerzalnosti i tko upravo u toj istoj univerzalnosti dobra pronalazi kriterij za svoje povijesno, konkretno i ograničeno, humano djelovanje. ${ }^{11}$ Teško je zanijekati tvrdnju da tako opisana humanost uvodi ne samo u bolje, dublje i potpunije razumijevanje ljudske naravi, nego i da se ista humanost očituje kao bitna odrednica ljudske seksualnosti. Može se ustvrditi da bilo koja analiza i tumačenje ljudske seksualnosti, ako žele uistinu biti čovjeku primjereni i racionalno prihvatljivi, moraju voditi računa o humanosti kao bitnoj i neupitnoj odrednici ljudske seksualnosti. ${ }^{12}$

Upravo istaknutomu svjedočanstvu iz svakidašnjeg iskustva i zdravog razuma, može se pridodati i nauk sv. Tome Akvinskog, koji također potvrđuje da je humanost autentična i temeljna odrednica ljudske seksualnosti. To proizlazi ne samo iz Akvinčeva izlaganja o naravnoj seksualnoj sklonosti, nego također iz skladne i duboko povezane strukture njegove Teološke sume. Kao što je poznato, svoj nauk o ljudskoj seksualnoj sklonosti Akvinac stavlja u širi okvir temeljnog antropološkog zakona, odnosno u drugi dio svoje trodijelne Teološke sume. Ako se zna da prvi dio Sume govori o Bogu, drugi o čovjeku, a treći o Kristu, i da su svi ti dijelovi skladno i organski povezani, onda je sasvim jasno da je Akvinčev nauk o seksualnoj naravnoj sklonosti sustavno i organski određen kako njegovom teologijom i kristologijom, tako isto i njegovom antropologijom. Autentična perspektiva Akvinčeva nauka o ljudskoj seksualnosti teološka je, ili bolje reći kristološka antropologija. Ona pak usmjerava pogled na »pravoga i savršenoga čovjeka «, ${ }^{13}$ tj. na onoga u kojem se prepoznaje ne samo istinska humanost, nego i kriterij za ispravno razumijevanje i tumačenje bilo koje ljudske dimenzije postojanja i djelovanja, uključujući i onu seksualnu.

11 Postoji krasan tekst sv. Augustina o ljudskoj usmjerenosti na dobro u svoj njegovoj univerzalnosti. Usp. Sveti Augustin, Trojstvo, Marijan Mandac (prev.), Split, 2012, VIII, 3; Servais Pinckaers, nav. dj., 410.

12 Usp. Servais Pinckaers, nav. dj., 438.

13 Usp. Drugi vatikanski koncil, Pastoralna konstitucija o Crkvi u suvremenom svijetu, Gaudium et spes, 22. U: Drugi vatikanski koncil, Dokumenti, Zagreb, 2008, 682-685. 
Međutim, čini se da je »humanost « kao pojam i svojevrsni kriterij ljudskog djelovanja u suvremenoj kulturi dobio toliko usko, ograničeno, površno i gotovo akcidentalno značenje u odnosu na čovjeka, njegovu narav i njegovo djelovanje da je humanost u svakidašnjem govoru gotovo neprimjereno primjenjivati na području ljudske seksualnosti. Na razini današnje kulture, ljudska seksualnost povezuje se daleko više s animalnošću nego li s humanošću. Ne ulazeći dublje u razloge, dobro je barem istaknuti činjenicu da najraširenije suvremene misaone kategorije razdvajaju humanost i ljudsku seksualnost do te mjere da se jedna i druga predstavljaju kao dvije gotovo nespojive kategorije. Za razliku od njih, Akvinčeve misaone kategorije, koje su puno šire, dublje i primjerenije čovjeku kao subjektu vlastitog postojanja i djelovanja, uvode svojeg čitatelja u perspektivu naravne seksualne sklonosti, polazeći upravo od onoga u čemu se humanost najviše prepoznaje, a to je ljudska razumna težnja prema istinskomu i potpunomu dobru. ${ }^{14}$

Tek nakon što je ukazao na prvobitnu ljudsku sklonost prema dobru i na prvobitni ljudski zakon »činiti dobro i prema njemu težiti, a zlo izbjegavati«, Akvinac tek tada upućuje na naravnu seksualnu sklonost, ističući da o prvobitnoj ljudskoj sklonosti ovise sve ostale ljudske sklonosti, odnosno da o prvobitnom ljudskom zakonu ovise sve ostale ljudske zapovijedi. Ako dakle naravna seksualna sklonost proizlazi i ovisi o prvobitnoj naravnoj sklonosti, odnosno ako naravna seksualna sklonost artikulira i konkretizira temeljnu naravnu sklonost i temeljni naravni zakon, onda je sasvim jasno da je naravna seksualna sklonost ne samo bitno određena i nužno povezana, nego i utemeljena u humanosti, koja je osobito prepoznatljiva u ljudskoj razumnoj težnji (volji) prema dobru u svoj njegovoj univerzalnosti. ${ }^{15}$

Imajući sve to na umu, sasvim je ispravno ustvrditi da je ljudska seksualnost sastavni dio jednog veoma složenog antropološkog dinamizma, koji polazi od prvih principa ljudskog postojanja i djelovanja. Taj izvorni, autentični, prvotni i naravni dinamizam oslanja se na načela koja su po sebi samima razumljiva i koja u čovjeku djeluju na razini same njegove ljudske naravi, bez obzira je li ih ili nije isti čovjek svjestan, bez obzira zna li ih ili ne zna jasno formulirati, bez obzira prihvaća li ih ili niječe u njihovim propozicijama. To je dinamizam koji nastoji, po samoj ljudskoj naravi, doprijeti do konkretnog ljudskog djelovanja, uključujući i ono seksualno, a oslanjajući se prije svega na naravne zapovijedi i naravne sklonosti, od kojih je prva sklonost prema dobru u svoj njegovoj univerzalnosti. Koliko je snažna, sveobuhvatna i sveprisutna ta prvobitna naravna sklonost, u kojoj čovjek prepoznaje svoj prvobitni i temeljni zakon, govori i činjenica da čovjek što god čini, to čini pod nekim vidom dobra. A to znači da je usmjeren na univerzalno dobro po samoj svojoj razumskoj, odnosno ljudskoj naravi, tj. ukoliko je čovjek, odnosno ukoliko je human. ${ }^{16}$

14 Usp. S. Thomae Aquinatis, nav. dj., vol. 2, I-II,94,2.

15 Usp. Servais Pinckaers, nav. dj., 406.

16 Usp. S. Thomae Aquinatis, nav. dj., vol. 1, I,82,1; vol. 2, I-II,94,2; vol. 3, II-II,25,2; Servais Pinckaers, nav. dj., 421. 


\subsection{Je li ljudska seksualnost nehumana?}

\subsubsection{Nehumanost kao neautentičnost i pokvarenost}

Ako je humanost autentična, bitna, utemeljujuća i supstancijalna sastavnica ljudske seksualnosti, je li uopće moguće govoriti o nehumanoj ljudskoj seksualnosti? U svakidašnjem govoru nerijetko se čuje da je netko nehuman, da je zvijer ili životinja, pa i sam vrag. Može li čovjek uistinu izgubiti svoju ljudsku narav i dobiti neku drugu, onu životinjsku ili onu anđeosku? Očito je da kod spomenutih tvrdnji nije riječ o ontološkoj i supstancijalnoj promjeni ljudske naravi u neku drugu narav, nego o ljudskoj neautentičnosti, odnosno o neskladu određenog ponašanja i djelovanja s ljudskom naravi koja je humana. Na sličan način govori se i o ljudskoj pokvarenosti. Misli se na pokvarenost određenog čovjeka, ukoliko se u njegovu ponašanju ne prepoznaje njegova autentična humanost kao najdublje načelo koje ga pokreće. Naime, ne dovodi se u pitanje je li neki čovjek po svojoj naravi čovjek ili nije, nego se propitkuje koliko se on ostvaruje kao »pravi čovjek« kroz svoje konkretno i povijesno djelovanje, kako bilo koje drugo, tako i ono seksualno.

Imajući u vidu dosada rečeno, dobro je istaknuti da ljudska narav nije samo dobra, nego da je i do te mjere postojana da se u konkretnom slučaju ni za kojeg čovjeka ne može govoriti o gubitku njegove vlastite ljudske naravi, nego samo o neautentičnosti i pokvarenosti iste naravi, odnosno pokvarenosti nekih njezinih načela u određenom konkretnom povijesnom slučaju. Koliko je zapravo postojana ljudska narav, svjedoči činjenica da je grijehom čovjek izgubio nadnaravnu izvornu milost, ali ne i svoju ljudsku narav, koju grijeh može pokvariti, ali ne i oduzeti je čovjeku, ili uništiti je u njemu dokraja. Na postojanost i neuništivost ljudske naravi između ostalog upućuje sljedeća trostruka razlika, koja je u svojem teološko-antropološkom nauku neupitna: a to je razlika između starog i novog čovjeka, jer i u jednom i u drugom slučaju riječ je o čovjeku, odnosno razlika između slike i sličnosti u čovjeku, jer prvo se ne može, a drugo može izgubiti, i konačno razlika između onoga što se ne može izbrisati, ali može izobličiti u čovjeku kao slici Božjoj. ${ }^{17}$

\subsubsection{Nehumanost kao posljedica krive antropologije}

U analizi i tumačenju suvremenog pojma ljudske seksualnosti, Pinckaers se ne zaustavlja samo na propitkivanju ostvaruje li se ili ne ostvaruje vlastita ljudska narav na razini ljudske seksualne aktivnosti, nego isto tako postavlja još dublje i temeljnije pitanje o pojmu same ljudske naravi, odnosno o razumijevanju čovjeka kao čovjeka. Naime, spoznaja ostvaruje li se ili ne ostvaruje čovjek kao čovjek na razini svoje seksualnosti pretpostavlja spoznaju čovjeka kao čovjeka. Upravo na toj izrazito antropološkoj razini spoznaje čovjeka kao čovjeka Pinckaers uočava

17 Usp. Ivan Golub, Slika i prilika Božja kod otaca, u: Milost: S predavanja, Zagreb, 1997, 39; Ivan Golub, Darovana slika, u: Prijatelj Božji, Zagreb, 1990, 91-155, osobito 101-102; S. Thomae Aquinatis, nav. dj., vol. 2, I-II,31,7. 
određenu nepravilnost, koja ima obilježje prije svega novovjekovnog dualizma. Korijene iste nepravilnosti on prepoznaje najprije u voluntarizmu koji dobiva jasne konture u misli Williama Occama (oko 1287. — oko 1347.), koji, u skladu sa svojim naukom o slobodi indiferentnosti, čovjeka svodi na njegovu volju, ${ }^{18}$ a zatim još više u idejama Renéa Descartesa (1596. - 1650.), koji u skladu sa svojim racionalizmom svodi čovjeka na njegov razum te dosljedno o čovjeku govori na posve dualistički način. ${ }^{19}$

Kao što je poznato, René Descartes vodeći je predstavnik racionalizma u 17. stoljeću. On je imao velik utjecaj na kasniju tradiciju, kako filozofsku, tako i teološku. U skladu s temeljnim postavkama Descartesova racionalizma, čovjek s lakoćom postaje čista misao, a ljudsko tijelo kao i njegova osjetilnost, odnosno seksualnost isto tako s lakoćom postaju puki biološki mehanizmi. Dolazi do stroge podjele između razumske i biološke, odnosno između duhovne i tjelesne dimenzije ljudskog postojanja. Razumski poredak odvaja se jasno i razgovijetno od osjetilnog, odnosno biološkog poretka. S jedne strane veliča se čovjek i hvali njegov razum, a s druge strane polako ali sustavno priprema pristup pun omalovažavanja i prezira prema ljudskom tijelu i njegovoj osjetilnosti, u kojima se kao kod životinje prepoznaje tek puki biološki mehanizam. Riječ je o posve jasnoj i razgovijetnoj dualističkoj antropologiji, koja vrlo lako dovodi do suženosti ljudske seksualnosti na razinu animalnosti i koja u konačnici seksualnosti priznaje samo biološku dimenziju i funkciju. Ukratko, riječ je o antropološkom dualizmu koji sustavno i snažno te jasno i razgovijetno dehumanizira ljudsku seksualnost.

Nažalost, u metafizičkoj podlozi mnogih suvremenih pozitivnih znanosti koje se na ovaj ili onaj način bave ljudskom seksualnošću, poput biologije, psihologije i sociologije, nerijetko se nalazi već spomenuti racionalizam sa svojim dualističkim poimanjem čovjeka, ljudske naravi i dosljedno ljudske seksualnosti. ${ }^{20}$ To osobito vrijedi za one pozitivne znanosti koje u svojim argumentacijama dolaze do zaključka da je dovoljno poštivati zakone na razini bioloških, fizioloških i sličnih procesa seksualnosti, kako bi se zajamčilo seksualno, odnosno tjelesno ljudsko zdravlje. Takav dualistički pogled na ljudsku seksualnost očito ostaje samo na tjelesnoj razini ljudskog postojanja i zanemaruje, ili bolje reći niječe duhovnu razinu. Imajući to na umu, Pinckaers s pravom tvrdi da je riječ o neprimjerenom, ograničenom i sasvim pogrešnom razumijevanju i tumačenju čovjeka, njegove naravi i dosljedno njegove seksualnosti. ${ }^{21}$

Naime, u onoj mjeri u kojoj se niječe supstancijalna povezanost i uzajamna određenost između ljudskog tijela i ljudskog duha, u toj istoj mjeri dehumanizira se čovjek kao čovjek kako na duhovnoj, tako i na tjelesnoj razini svojeg postojanja. Kriterij za primjereno i ispravno vrednovanje ljudske seksualnosti nije samo tjelesna, nego i duhovna dimenzija ljudskog postojanja, a to znači jedinstveni i

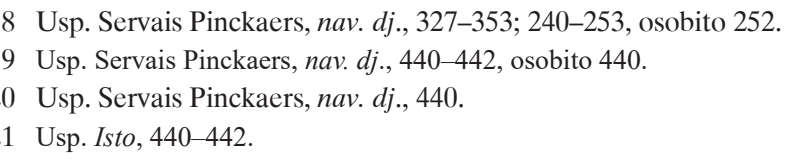


cjeloviti čovjek koji se uvijek treba razumijevati kao utjelovljeni duh ili pak kao produhovljeno tijelo. Da bi se čovjeka uistinu poštivalo kao čovjeka, ne smije se ni njegovu duhu nijekati utjelovljenost ni njegovu tijelu, i dosljedno seksualnosti, oduzimati produhovljenost. U protivnom, i u jednom i u drugom slučaju, dehumanizira se čovjek kao čovjek u svojoj jedinstvenoj i cjelovitoj supstancijalnoj naravi. I na kraju, kao uvod u završni dio trećeg dijela članka, dobro je istaknuti da spomenuti antropološki dualistički pristup, svojim nijekanjem supstancijalnoga jedinstva ljudskog duha i tijela, zapravo niječe ne samo jedinstvenu i cjelovitu ljudsku narav, nego i samu ljudsku osobu koja ostvaruje ljudsku narav i koja upravo u naravi pronalazi svoju najdublju i temeljnu određenost. ${ }^{22}$

\subsection{Ukorijenjenost seksualnosti u ljudskoj osobi}

Već je istaknuto da je nemoguće ispravno razumjeti i tumačiti ljudsku seksualnost bez njezina odnosa prema ljudskoj naravi i prema supstancijalnomu jedinstvu iste naravi. Međutim, valja istaknuti da ljudsko biće i ljudska seksualnost nisu dokraja određeni i ne iscrpljuju se u pojmovima kao što su narav i supstancija, koliko u pojmu osobe koja ukazuje na individualnu subzistentnost u duhovnom poretku. Ne ulazeći dublje u nauk o ljudskoj osobi, dobro je istaknuti da se on osobito razvijao pod utjecajem kršćanske misli i da je svoj vrhunac na neki način dosegnuo u misli sv. Tome Akvinskog, koji u skladu sa svojom filozofijom bitka u osobi prepoznaje »ono što je najsavršenije u cijeloj naravi«.23

Zajedno s Boecijem, sv. Toma Akvinski ukazuje na ontološku i duhovnu dimenziju kao na bitne elemente ljudske osobe. Prema Akvincu, u inteligentnoj supstanciji kao što je osoba nalazi se najsavršeniji oblik subzistentnosti jer je, između ostalog, osoba obdarena i vlašću nad vlastitim djelovanjem. Dapače, u toj vlasti, ili bolje reći slobodi koja proizlazi iz inteligencije i volje, sv. Toma Akvinski prepoznaje Božju sliku u ljudskoj osobi, ${ }^{24}$ a sveukupna kršćanska tradicija u istoj slobodi prepoznaje uvjet ljudskog odgovora na Božji poziv. ${ }^{25}$ Zato, u skladu s Akvinčevim pojmom osobe kao najvišim stupnjem savršenosti u cijeloj naravi, kao i u skladu s Boecijevom (480. - 524.) ontološkom definicijom osobe, čovjeka je daleko primjerenije nazivati osobom nego supstancijom ili nekim imenom koji ukazuje tek na narav. Slično tvrdi i Pinckaers kada veli da osoba najpotpunije ostvaruje supstanciju, jer supstancijalnim određenjima kao što su subzistentnost, subjektnost, individualnost i narav osoba dodaje i ono što čovjeka razlikuje od životinje, a to je razumnost, razumna volja i vlast nad vlastitim činima. ${ }^{26}$

22 Usp. Papinska međunarodna teološka komisija, nav. dj., 68; 70; Sancti Thomae de Aquino, Scriptum super Sententiis, vol 3, III,5,1,3, Parmae, 1858. URL: http://www.corpusthomisticum.org/snp30 05.html (preuzeto 05.12.2016); Ivan Pavao II., Veritatis splendor, 50, Zagreb, 2008.

23 Usp. S. Thomae Aquinatis, nav. dj., vol. 1, I,29,3; Sancti Thomae de Aquino, Quaestiones disputatae de potentia, 7,2,9, Taurini, 1953. URL: http://www.corpusthomisticum.org/qdp7.html (preuzeto 05.11.2016.)

24 Usp. S. Thomae Aquinatis, nav. dj., vol. 2, I-II, Prologus.

25 Usp. Papinska međunarodna teološka komisija, nav. dj., 67.

26 Usp. Servais Pinckaers, nav. dj., 423-426, osobito 423. 
Stoga, ako je čovjeka primjerenije nazivati osobom nego li supstancijom, jer se na taj način izričito vrednuje ljudska razumnost, razumska volja i neotuđiva ljudska sloboda, onda je isto tako primjerenije govoriti o osobnom, a ne samo supstancijalnom jedinstvu ljudskog bića. Onaj tko promišlja ljudsko tijelo, ne promišlja tek supstancijalno tijelo, nego tijelo ljudske osobe koja je stvorena na Božju sliku. Onaj tko tumači ljudsku seksualnost, ne tumači tek seksualnost jedne naravi, nego tumači seksualnost ljudske osobe koja je obdarena vlašću nad vlastitim činima. Onaj tko analizira ljudsko seksualno ponašanje, ne analizira tek izvanjsko ljudsko seksualno ponašanje, nego analizira seksualno ponašanje ljudske osobe koja ima razum i razumnu volju. Uostalom, ljudska je osoba najviše i jedino unutarnje načelo koje uspostavlja jedinstvo i ostvaruje komunikaciju različitih dimenzija ljudskog bića. U konkretnoj i jedinstvenoj ljudskoj osobi, duhovna i tjelesna dimenzija nisu ni pomiješane ni odvojene, nego sjedinjene, i pokoravaju se prije svega onomu što je u njima supstancijalno, bitno i njihovo najviše načelo, a to je sama osoba, tj. individualna supstancija razumske naravi. ${ }^{27}$

Na temelju svega do sada rečenog može se ustvrditi da ljudska seksualnost nužno i bitno ovisi o ljudskoj osobi i da u njoj ima svoje najviše načelo te najdublji temelj postojanja i temeljnu odrednicu svojeg djelovanja. To znači da uz tjelesnu i biološku, ljudska seksualnost ima također osobnu i dosljedno duhovnu dimenziju. Upravo na to misli i Pinckaers kada tvrdi da ljudska seksualnost dobiva psihološku, moralnu i duhovnu dimenziju, odnosno da ljudski duh prodire do seksualnosti da bi je uskladio sa svojim zahtjevima i u njoj se dokraja ostvario. ${ }^{28}$ Na toj je liniji i Papinska međunarodna teološka komisija kada govori o sjedinjenosti i usklađenosti seksualne s osobnom dimenzijom ljudskog postojanja, odnosno kada govori o svojevrsnom procesu humanizacije onoga što je upisano kao obećanje u ljudsko tijelo, odnosno u ljudsku seksualnu sklonost. ${ }^{29}$ Vodeći računa o svemu dosada rečenom, dobro je istaknuti da se duboka osobna povezanost između ljudskog duha i tijela, kao i humanizirajući odnos ljudske osobe prema ljudskoj seksualnosti u njezinu fizičkom i biološkom značenju, daju prepoznati na različitim razinama ljudskog postojanja, kao što su naravna, misaona i iskustvena razina. Na svim tim razinama može se zapaziti ne samo osobni, nego i humanizirajući odnos.

Naime, na razini naravne seksualne sklonosti u njezinu fizičkom i biološkom značenju, na razini koja je čovjeku zajednička sa svim životinjama, ostvaruje se na poseban način sklonost prema društvu, a to je izrazito antropološka sklonost, sklonost koja je posebnost i vlastitost ljudske razumske, odnosno duhovne naravi. Taj dublji pristup i humano tumačenje naravnih dinamizama ljudske osobe poglavito je prisutan u bogatoj i plodnoj misaonoj baštini antičke i skolastičke tradicije, koja uz tjelesnu ukazuje osobito na duhovnu dimenziju, primjerice na

27 Usp. Papinska međunarodna teološka komisija, nav. dj., 79; Usp. Drugi vatikanski koncil, nav. dj., $\mathrm{DH}, 2-3$.

28 Usp. Servais Pinckaers, nav. dj., 441.

29 Usp. Papinska međunarodna teološka komisija, nav. dj., 79. 
razini ciljeva braka. Istaknuti predstavnik te tradicije svakako je sv. Toma Akvinski, koji se u svojem tumačenju naravnih ciljeva braka prije svega usredotočuje na ono što je u braku vlastito ljudskoj naravi u njezino najistaknutijem smislu. Primjerice, kada govori o prokreaciji, Akvinac ne govori toliko o samom rađanju potomstva (generatio prolis), koliko o dobru potomstva (bonum prolis). ${ }^{30}$ Isto tako kada govori o uzajamnoj potpori supružnika, Akvinac ne govori toliko o onoj fizičkoj, koliko o duhovnoj uzajamnoj potpori koja se prije svega očituje u prijateljstvu i bračnoj ljubavi. ${ }^{31}$ Koliko je na toj liniji također i najistaknutiji predstavnik antičke filozofske misli, govori činjenica da odnos između muškarca i žene u braku Aristotel analizira unutar svojeg nauka o prijateljstvu, koje je izrazito antropološka, humana, osobna i duhovna, a ne fizička ili biološka kategorija. ${ }^{32}$

I konačno, na razini konkretnog ljudskog iskustva može se uočiti duboka povezanost između ljudskog duha i tijela, kao i humanizirajući odnos između ljudske osobe i njezine seksualnosti u fizičkom i biološkom značenju. Između ostalog, teško je zanijekati činjenicu, dostupnu svačijemu zdravomu razumu, da ljudska seksualna sklonost uspostavlja odnos između muškarca i žene ne samo na onoj izvanjskoj tjelesnoj, nego i onoj unutarnjoj, dubokoj osobnoj razini njihova postojanja i djelovanja. A to se događa prije svega zato što je ljudska seksualnost duboko ukorijenjena i utemeljena u ljudskoj osobi i njezinoj razumskoj ili bolje reći duhovnoj naravi.

\section{Zaključak}

Animalnost ukazuje na obdarenost životom i osjetilnošću, a humanost ukazuje na obdarenost ne samo osjetilnošću, nego i razumnošću. Osjetilna i razumna, odnosno tjelesna i duhovna dimenzija ljudske seksualnosti supstancijalno su povezane na razini jedne jedinstvene ljudske naravi. Stoga, razumijevanje i tumačenje ljudske seksualnosti moraju voditi računa o jednoj jedinoj, jedinstvenoj i cjelovitoj ljudskoj naravi, odnosno moraju voditi računa o humanosti kao bitnoj, neupitnoj i temeljnoj odrednici ljudske seksualnosti. Nadalje, ako djelovanje proizlazi iz naravi, i dosljedno ljudsko djelovanje iz ljudske naravi, onda se istinska ljudska narav očituje u istinskom ljudskom djelovanju. Drugim riječima, ako se humanost izražava u humanom djelovanju, koje je po samoj svojoj humanoj naravi usmjereno na istinsko i potpuno dobro, onda je i autentično seksualno djelovanje čovjeka, po samoj svojoj humanoj naravi, usmjereno na dobro u svoj njegovoj univerzalnosti. Ljudsku seksualnost ne određuje toliko ni njezina animalnost ni njezina racionalnost, koliko njihovo supstancijalno jedinstvo, odnosno jedna jedina i cjelovita ljudska narav. Međutim, dobro je imati na umu da nazivi kao što su narav i supstancija također ne određuju sasvim dokraja konkretno ljudsko biće, i dosljedno njegovu seksualnost, u njezinoj sveukupnosti. Čovjeka,

30 Usp. S. Thomae Aquinatis, nav. dj., vol. 5, III, Supplementum, 41,1.

31 Usp. Isto.

32 Usp. Aristotel, Nikomahova etika, Tomisalv Ladan (prev.), Zagreb, 1982, VIII; XII. 
kao i njegovu seksualnost, određuje potpuno tek pojam osobe, koji ukazuje na individualnu subzistentnost $\mathrm{u}$ duhovnom poretku, i koji izričito upućuje na obdarenost vlašću nad vlastitim djelovanjem. To znači da, uz tjelesnu i racionalnu, ljudska seksualnost ima također i osobnu dimenziju.

Uz animalnu, te humanu i dosljedno osobnu dimenziju, ne smijemo zaboraviti i na onu najdublju dimenziju ljudske seksualnosti, a to je njezina nadnaravna dimenzija. Premda se članak nije izričito bavio upravo istaknutom dimenzijom ljudske seksualnosti, na nju je u više navrata i na više načina upućivao. Primjerice kada je riječ o ljudskoj seksualnosti u njezinom fizičkom značenju, istaknuto je da osoba, osim što iščitava moralnu poruku, također ostvaruje obećanje koje je upisano u ljudsko seksualno tijelo. Isto tako, kada je riječ o ljudskoj seksualnosti u njezinu najistaknutijem osobnom značenju, naglašeno je da se čovjek kao čovjek ostvaruje u svojem seksualnom djelovanju u onoj mjeri u kojoj se $\mathrm{u}$ istom svojem djelovanju usmjerava prema istinskomu i potpunomu dobru. I u jednom i u drugom slučaju, upućuje se na odnos prema nadnaravnoj dimenziji ljudske seksualnosti. Na tu dimenziju svraća pozornost i sv. Toma Akvinski kada svoj nauk o naravnoj seksualnoj sklonosti stavlja ne samo u antropološki kontekst, nego također u široke i duboke teološke perspektive. Nadalje, ako su u ljudsko seksualno tijelo upisani moralna poruka i obećanje, onda ih je netko morao upisati. Isto tako, ako je čovjek po samoj svojoj ljudskoj naravi usmjeren na istinsko i potpuno dobro u svoj njegovoj univerzalnosti, onda ga je netko na nj usmjerio. Stoga, bez obzira je li riječ o moralnoj poruci, obećanju, usmjerenosti, ili pak o ljudskoj slobodi, uvijek se zapravo ukazuje na onu nadnaravnu dimenziju ljudske seksualnosti koja seksualnosti daje njezino najdublje i najprimjerenije utemeljenje.

Na tragu Servaisa Pinckaersa i sv. Tome Akvinskog, kao i nedavnih dokumenata crkvenog učiteljstva, moguće je kratko i sažeto ustvrditi da primjereno i racionalno prihvatljivo vrednovanje ljudske seksualnosti, uz fizičku, biološku i tjelesnu, uključuje također onu humanu, osobnu i nadnaravnu datost ljudskog bića. Ljudska seksualnost ne tiče se tek fizičkih čina, bioloških procesa i tjelesnog zdravlja. Ona je konstitutivna sastavnica ljudske osobe, neupitni i neotuđivi sastavni dio jedinstvenog i cjelovitog antropološkoga dinamizma, koji je naročito prepoznatljiv po humanosti kao osobnoj usmjerenosti na istinsko i potpuno dobro, na dobro u svoj njegovoj univerzalnosti. 


\section{Is Human Sexuality Human and Personal?}

\section{Tadija Milikić*}

\section{Summary}

The paper strives to contribute to an understanding of human sexuality chiefly from the perspective of the Belgian moral theologian Servais Pinckaers who endeavours to follow Aquinas' thought and is in line with the most recent documents of the Magisterium. The first and second sections contribute to a more accurate interpretation of the »animal « and »natural « dimension of human sexuality in highlighting that human sexuality indeed has both an animal and natural dimension, but that it must not be reduced to any sort of animal sexuality or nature which would not be a singular and unique human nature. The third and most important section of the article strives to point out the human and personal dimension of sexuality as being that without which human sexuality is inconceivable, or rather, as that which gives human sexuality its particular, proper and inalienable anthropological value. And finally, the reflection permeating the article indirectly points to the supernatural dimension of human sexuality.

Key words: sexuality, animality, naturality, substantial unity, humaneness, good, person, Servais Pinckaers, St. Thomas Aquinas

* Senior Assistant Tadija Milikić, Ph.D., University of Zagreb - The Faculty of Philosophy and Religious Studies in Zagreb. Address: Jordanovac 110, 10000 Zagreb, Croatia. E-mail: tmilikic@ ffdi.hr 